\section{KEEPING THE CQC INSPECTOR HAPPY}

The 2015 British Dental Conference and Exhibition will provide a perfect opportunity to update visitors on what's new at Belmont. Chances are many practitioners haven't purchased a new chair for a while and will be amazed at how technology has evolved.

Belmont's streamlined equipment, with easily cleanable upholstery that's resistant to both bacteria and staining, will benefit both patient and practitioner. The former will receive treatment in comfort, whilst the latter will benefit from improved ease of access as well as keeping the CQC inspectors happy.

For those who wish their surgery were a little bigger, why not take a look at the Cleo, which has a folding leg rest? Not only does this have a much smaller footprint, making your surgery look bigger, it also has many benefits for the patient. Access is easy; it's just like getting into a 'normal chair', which will be a relief to all, especially elderly, disabled or younger patients.

As is always the case, there will also be some tempting offers for those who like what they see and want to benefit from the cost savings available throughout the duration of the show.

\title{
CUTTING-EDGE X-RAY SOLUTIONS
}

Clark Dental will be among the leading exhibitors welcoming delegates at this year's British Dental Conference and Exhibition, showcasing the latest innovations in the UK market.

Visitors to the stand will discover the new NOMAD ${ }^{\circledR}$ Pro 2 handheld $\mathrm{X}$-ray machine. Delivering images of outstanding quality, it enables professionals to remain with the patient during the X-ray process.

Delegates can also learn about the Sirona ORTHOPHOS XG 3D and the many benefits of a fully digital panoramic OPG combined with the latest 3D technology. The Clark Dental team will be on hand to demonstrate Schick 33, the latest module in the state-of-the-art Schick Digital Imaging System, offering an industry-leading resolution of 33 line pairs per millimetre.

Attendees will also explore the smart thinking Florida Probe, providing real-time audio commentary for periodontal exams. As well as the new innovative VoiceWorks voice-controlled perio charting system that lets even complex examinations be completed in as little as 10 minutes.

To discover how your practice could benefit from the latest cutting-edge solutions, visit Clark Dental at this year's British Dental Conference and Exhibition. Alternatively, call 01268733 146, email info@ clarkdental.co.uk or visit www.clarkdental.co.uk.

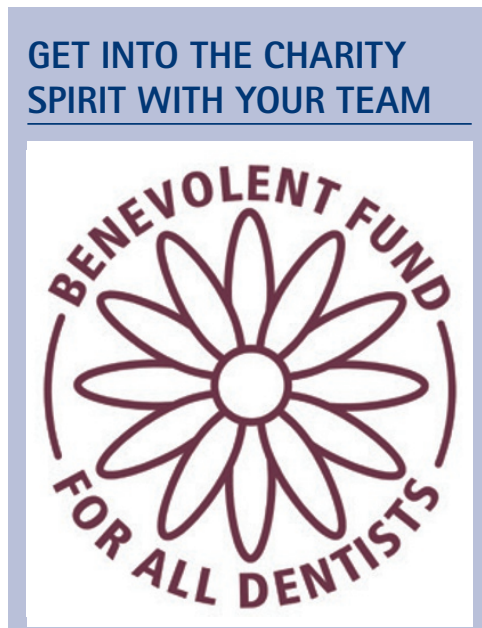

Come and have your photo taken on Friday 8 May on Stand C45 at the British Dental Conference and Exhibition. We need fun 'I support' photos for the Benevolent Fund's Charity Gallery, everyone welcomed. Create a memorable moment with friends and colleagues; photos are available to keep for a small donation.

The BDA Benevolent Fund has been helping dentists in need for over 125 years and needs your help now more than ever. Any support you can give will be much appreciated.

Visit the BDA Benevolent Fund at stand C45.

\section{TRAIN THE TALENT OF TOMORROW}

Dental practices can look forward to two brilliant apprenticeships thanks to the Government's Trailblazer initiative phases 2 and 3.

The standards for these exciting apprenticeships have been specifically developed by leading employers and professional bodies and led by Mustafa Mohamed, Chair of the Trailblazer project in Dental Health, and owner and founder of Genix Healthcare and Sparkle Dental Labs.

Being employer-led, apprenticeships are guaranteed to meet the needs of practices both large and small. Currently, 96\% of employers that take on an apprentice report advantages to their business, ${ }^{1}$ and $74 \%$ of small to medium-sized enterprises in the UK believe recruiting apprentices is crucial for their future growth. ${ }^{2}$
Through quality on-the-job, practical training, individuals will get the chance to gain the necessary skills and recognised qualifications to excel, while businesses can benefit from a loyal, dedicated and motivated workforce. For additional information from the National Apprenticeship Service, visit www.apprenticeship. org.uk. For more details about Sparkle Dental Labs, call 0800138 6255, email customerservice@ sparkledentallabs.com or visit www. sparkledentallabs.com.

1. Apprenticeships. About Apprenticeships. Available online at http://webarchive. nationalarchives.gov.uk/20141006151154/ http://www.apprenticeships.org.uk/employers/the-basics.aspx (accessed March 2015).

2. The 5\% Club. The 5\% Club celebrates first anniversary. 2014. Available online at http://5percentclubblog.org (accessed March 2015).

\section{SEE ALL THE LATEST GC INNOVATIONS AT THE BDA CONFERENCE!}

GC will be exhibiting all their latest innovations at the 2015 British Dental Conference and Exhibition, as well as all their tried and trusted favourites.

of particular interest will be MI Varnish for patients at risk of hypersensitivity, Ceramic Primer 2 which facilitates adhesive bonding of composites to ceramics, and G-CEM LinkAce GC's dual-curing, self-adhesive, universal resin cement for adhesive luting of allceramic, metal and composite indirect restorations.

For more information call GC UK Ltd on 01908 218999, e-mail info@gcukltd.co.uk or visit www.gceurope.com.

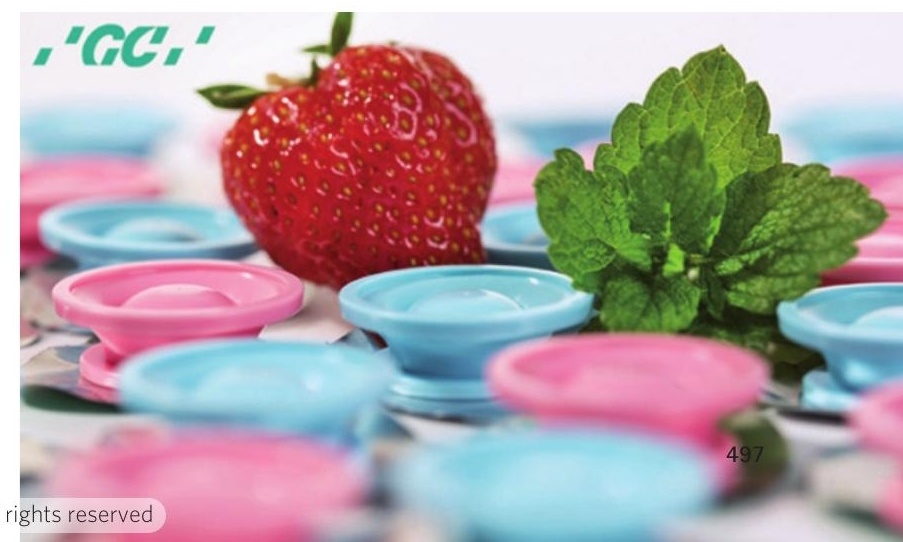

